\title{
The Effect of the Using of ICT-Based Media and Learning Interest to the Students' Learning Results
}

\author{
Siti Asiah ${ }^{1}$, Herson Anwar ${ }^{2}$ \\ asiahpido@iaingorontalo.ac.id,herson.anwar@iaingorontalo.ac.id
}

IAIN Sultan Amai Gorontalo, Gorontalo, Indonesia

\begin{abstract}
The perspective of learning theory states that many factors that affect students' learning result, whether internally or externally. The internal factor such as the using of ICTbased learning media and learning interest which are assumed strongly affect the students' learning results. This research was quantitative research by using interpretive research approach with the sample 161 students taken from State Junior High School Gorontalo City at academic year 2017/2018. The collecting of the data was conducted through the observation, questionnaire, and documentation. The data analysis technique used in this research was multiple linear regression analysis using the estimation model of Metode Ordinary Least Square $(O L S)$. The result showed that the utilization of ICT-based learning media had positive and significant effects on the students' learning results. In the same way, students' learning interest also positively and significantly affected the learning results of students. Besides that, the finding also showed that the using of ICT-based media and learning interest simultaneously had positive and significant effects on the students' learning results.
\end{abstract}

Keywords: ICT Media, Learning Interest, learning the result

\section{INTRODUCTION}

One indicator and benchmark of students' success in the learning process is the learning result. The learning result is affected by one external factor from the students. That external factor is the availability of the learning media which gives the easiness for the students to learn the material. Besides that, it is also affected by one internal factor from students that is the learning interest. Therefore, the use of information and communications technology (ICT)-based media, and learning interest are strongly assumed had a significant effect on the students' learning results.

ICT is the combination of three words: information, communication, and technology, "a combination of technological tools and resources that are used to manipulate and communication the information, here technological tools are the electronic and digital devices like computers, Internet and broadcasting technologies, etc [1]. By the developing of relevant technology and communication, the learning based on the technology will be readily accepted by the students, and this thing is the responsibility of the teachers for teaching the students in achieving the knowledge systematically with the correct conceptual understanding through the information network and communication technology [2]. The utilization of ICT-based media gives the effects through the motivation, interest, learning activity, learning result, and the attainment of learning achievement. In the other sides of the using of ICT in learning is more effective and efficient and also makes learning becoming more interesting [3]. Therefore, it is crucial for the teachers to adapt with the recent learning's needs by utilizing the ICT-based media to give excellent learning to students and also make them possible to obtain the learning result which fulfills the minimal passing criteria. 
Furthermore, students' learning interest needs to be improved, because learning interest is one internal factor which affects the learning results. Learning interest is the pleasure choice in doing activities and can raise the passion of students in fulfilling their willingness in learning [4]. The raising of interest inside students will create the attention and willingness to do something diligently in the long term period, can be more concentrated, can be easier to remember and hard to be bored with the material which they learn [5]. The better or higher the interest level of students, the better or higher the achievement that they can achieve. Otherwise, if the students' awareness to improve their learning interest still lack, so their achievement will be more decreased [6].

Because the importance of the using of ICT-based learning media to the students' result in the learning process, the researchers are interested in knowing the effect of the use of ICTbased learning media and students' interest to the students' learning results in the subject of Islamic education. Some general problems in the Islamic education learning such as the learning in the class are dominantly presented in the form of teachers' speech, and the students should memorize the materials without any helps of the learning media. The lack of interest, fondness, attention, and the involvement of the students in learning, so it makes the learning results of the students still have not reached the minimal passing criteria. Hence, the utilization of ICT-based learning media and the learning interest of students are assumed to affect the students' learning results.

\section{METHOD}

\section{A. The Research Design}

This research was quantitative research which emphasized the test of the theories through the measurement of the research variables with the number and also needed the data analysis with the statistical procedure. The quantitative research was also known as the research which based on the positivism philosophy, and it was used to research the population or the individual sample, the data collection in this research used the research instrument, quantitative/statistic data analysis, with the purpose to examine the hypothesis. This research used the descriptive research approach to examine the hypothesized variables. This hypothesis described the relationship between two variables, to know whether the variables were associated with the other variables or not, or whether the variables were caused or affected by the other variables or not.

\section{B. Population and Sample}

The population in this research was the students in a junior high school at Gorontalo City, academic year 2017/2018 consisted of 336 students with 186 male students and 150 female students.

The sampling technique in this research used the proportional random sampling, and the determination of the quantity of the sample used Nomogram Harry King table, with the error level of $5 \%$. With the number of population of 336 students, it was made a line across the error level $5 \%$, and it was found the point above 40 , for the error level $5 \%$ meant that the trust level was $95 \%$, so the multiplying factor $=1,195$. So the number of the sample was 0,40 x 336 x $1,195=160,74$ and rounded up becoming 161 samples.

\section{The Data Collecting Technique}

The data collecting technique used in this research was conducted through the observation, questionnaire, and the documentation technique. The observation was conducted to observe the learning condition in the class by using ICT-based and also was used to observe the 
learning interest of the students. The questionnaire was used to obtain the data score from the variables of the using of ICT-based learning media and students' learning interest which were shown to the students as the respondent. The questionnaire used in this research was using the Likert scale from scale 5 with two kinds of favorable and unfavorable statements. For the favourable statement (the supporting statement which showed the measured attributes, such as $5=$ always, $4=$ often, sometimes $=3$, seldom $=2$, and never $=1$ ) and the unfavorable statement (the statement which did not support or did not describe the characteristics of the measured attributes, such as $1=$ always, $2=$ often, sometimes $=3$, seldom $=4$, and never $=5$ ).. The documentation technique used to obtain the data of students' learning results in the subject of Islamic education from the daily examination, mid-term examination and the final semester examination at second semester at academic year 2017/2018.

\section{Analysis Data}

The data which had been collected was analyzed. The regression analysis conducted the data analysis in testing hypotheses in this research. Because the independent variable was more than one variable, multiple linear regression analysis was performed. The multiple regression used in this study used the estimation model of Ordinary Least Square (OLS). Multiple regression analysis was used to determine whether or not there was an influence between the size of the dependent variable and the independent variable through the formula equation as followed:

Where:

$$
\mathrm{Y}=\beta_{1} \mathrm{X}_{1}+\beta_{2} \mathrm{X}_{2} \ldots .+\mathrm{e}
$$

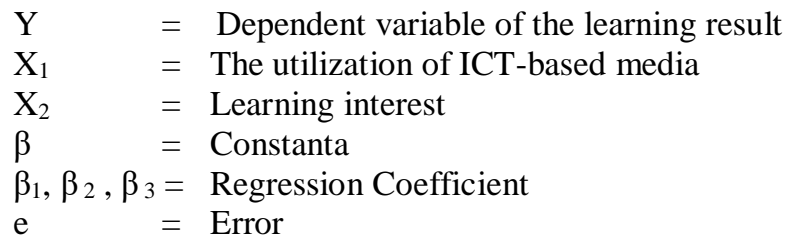

The hypothesis testing was done partially (t-test) and simultaneously (F test). To see how much independent variables explained the dependent variable, it was necessary to find the determination coefficient values (R2).

\section{RESULT AND DISCUSSIONS}

The findings of the research through the questionnaire processing related to each research variable based on the analysis of research data using the help of the SPSS 24.0 software program were described as followed.

\section{The Use of ICT-based Media}

The use of ICT-based learning media in this research was the tools in delivering the messages or materials in the form of slides in the power point presentation which consisted of text, picture, animation, video, and audio, so the students accepted the messages and improving their learning results. This variable was measured through the three indicators; they were: the availability and the frequency of the user of the media, the appropriateness with the students' characteristics, learning objective, the learning material, and time allocation, and the skill in the using of the learning media. The data score of the variables of the using of ICTbased learning media obtained from the answers of the respondents were 161 from 33 question items in the questionnaire. 
Based on the descriptive statistics, the average score was 4,448 , the standard deviation was 0.221 with the lowest score was 3.79 , and the highest score was 4.91 . The median obtained was 4.45 . The most appearing score or the mode value was 4.42 . The variance of 0.0489 indicated the diversity of data. Furthermore, the concentration value was calculated based on the ideal standard assumption (normal curve), that was the concentration of the values by finding the ideal maximum score, ideal minimum score, ideal mean (Mi) and ideal standard deviation (SDi). The formula used to find the ideal average (Mi) was $1 / 2$ (ideal maximum score + ideal minimum score $)$ so that $\mathrm{Mi}=1 / 2(4.91+3.79)=4.35$ and to find the ideal standard deviation was used formula $1 / 6$ (maximum ideal score - ideal minimum score) was SDI $=1 / 6(4.91-3.79)=0.19$. Furthermore, the ideal standard deviation value (SDi) and the mean / ideal mean (Mi) were converted into 5 (five) tendency score categories. The conclusion of the analysis of the description of the variable frequency scores of the use of ICT-based learning media was analyzed by using SPSS in the descriptive statistics and obtained the outputs as shown in Table I:

TABLE I.
\begin{tabular}{ccccc}
\multicolumn{4}{c}{ THE TENDENCY OF THE SCORE VARIABLE OF THE USE OF ICE-BASED MEDIA } \\
\hline Interval & Frequency $(\mathrm{f})$ & Percentage $(\%)$ & Category \\
\hline $4.64-4.92$ & 38 & 23.60 & Very High \\
\hline $4.45-4.63$ & 53 & 32.92 & High \\
\hline $4.26-4.44$ & 45 & 27.95 & Moderate \\
\hline $4.07-4.25$ & 15 & 9.32 & Low \\
\hline $3.78-4.06$ & 10 & 6.21 & Very Low \\
\hline Total & 161 & 100 & \\
\hline
\end{tabular}

Table I showed the tendency of the variable scores using ICT-based learning media based on the categories that had the highest frequency was in the interval score of $4.45-4.63$, that were 53 respondents with a percentage of $32.92 \%$ in the high category, while the lowest frequency was at the interval score of $3.78-4.06$ with 10 respondents or $6.21 \%$. Hence, it was concluded that the average variable score of the use of ICT-based learning media was included in the high category. This meant that based on respondents' responses, the use of ICT-based learning media had high intensity in classroom learning.

\section{Learning Interest}

The learning interest, in this case, was the involvement of the students with all activities wich was conducted with the full attention to obtain the knowledge and achieved the understanding of the materials which were learned. Then, the learning interest in this research was measured by using four indicators; they were: interest, attention, motivation, and knowledge. The data score from the variables of students' learning interest in this research was obtained from the respondents consisted of 161 students from 37 question items in the questionnaire.

Based on the output statistics descriptive obtained an average score of 4.39 , the standard deviation of 0.276 with the lowest score of 3.81 and the highest score of 5 . The median obtained was 4.35 . The most appearing score or the mode value was 4.3. The diversity of data was indicated by the variance of 0.0760 . Next, the concentration value was calculated, obtained $\mathrm{Mi}=1 / 2(5+3.81)=4.41$ and to find the ideal standard deviation, the formula $1 / 6$ (ideal maximum score - ideal minimum score) was SDI $=1 / 6(5-3.81)=0.20$ which was converted into 5 (five) the tendency score categories. The conclusion of the description 
analysis of the frequency of scores of learning interest variables was analyzed using the SPSS program with the descriptive statistics obtained by the output as shown in Table II:

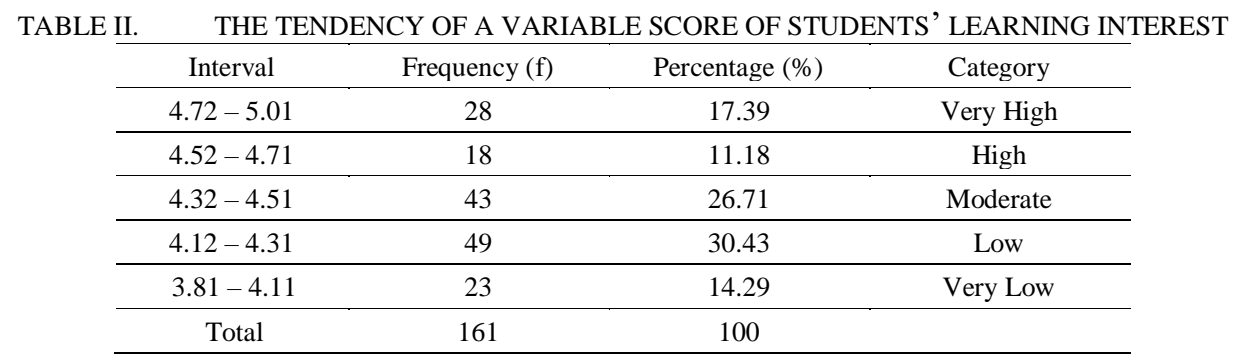

Table II showed the tendency of the score of learning interest variables based on the categories that had the highest frequency was in the interval score 4.12 - 4.31 with 49 respondents or $30.43 \%$ in the low category. However, when viewed from the average percentage of statements the positive response given was in the very high category of $17.39 \%$, the high category was $11.18 \%$, and the medium category was $26.71 \%$ so that if accumulated as a whole was $55.28 \%$. Furthermore, it was concluded that the average score of the variable interest in learning was included in the high category. This meant that students' learning interest was high in the learning process in the classroom.

\section{Learning Results}

The learning result in this research referred to the average value of students in the learning of Islamic Education obtained from the results of the daily examination, midterm exams and the final semester examination in the first semester of academic year 2017/2018.

Based on the statistics descriptive output, it was obtained an average score of 7.85 , the standard deviation of 0.438 with the lowest value of 6.76 and the highest value of 9.62. The median obtained was 7.74. The most appearing score or the mode value was 7.69. The diversity of data was shown by the variance of 0 . 1920. Furthermore, the concentration value was calculated and obtained $\mathrm{Mi}=1 / 2(9.62+6.76)=8.19$ and to find the ideal standard deviation used formula $1 / 6$ (ideal maximum score - ideal minimum score) was SDI $=1 / 6$ $(9.62-6.76)=0.48$ which was converted into 5 (five) score categories of tendency. The conclusion of the description analysis of the frequency of scores of learning interest variables was analyzed using SPSS assistance with descriptive statistics obtained by the output as shown in Table III below:

TABLE III. THE TENDENCY OF A VARIABLE SCORE OF STUDENTS' LEARNING RESULTS

\begin{tabular}{cccc}
\hline Interval & Frequency (f) & Percentage (\%) & Category \\
\hline $8.92-9.63$ & 14 & 8.70 & Very High \\
\hline $8.44-8.91$ & 99 & 61.49 & High \\
\hline $7.96-8.43$ & 29 & 18.01 & Moderate \\
\hline $7.48-7.95$ & 16 & 9.94 & Low \\
\hline $6.75-7.47$ & 3 & 1.86 & Very Low \\
\hline Total & 161 & 100 &
\end{tabular}

Table III showed that the tendency of the students' learning result variable scores based on the categories that had the highest frequency was in the interval value of $8.44-8.91$ that 
was a number of 99 respondents with a percentage of $61.49 \%$ in the high category. Furthermore, it was concluded that the average learning result variable was included in the high category. This meant that the students' learning results in the class were high in the range of values $8.44-8.91$

The data from this research were passed the pre-requirement assumption test and the results fulfilled the Best Linear Unbiased Estimator (BLUE) Standard. Then, It was conducted the multiple linear regression analysis and the processing process of the research was conducted using the SPSS software version 24.0 which obtained a summary of the analysis as in table IV:

\begin{tabular}{|c|c|c|c|}
\hline \multicolumn{4}{|l|}{ TABLE IV. } \\
\hline Variable & Coefficient & $\mathrm{t}$ & Sig \\
\hline $\begin{array}{l}\text { The Utilization of } \\
\text { the ICT-Based } \\
\text { Media }\end{array}$ & 0.774 & 6.616 & 0.000 \\
\hline Learning Interest & 0.769 & 8.203 & 0.000 \\
\hline Constanta & 1.031 & 1.823 & 0.070 \\
\hline
\end{tabular}

Based on the results of the regression analysis, it was obtained the regression equation: $\mathrm{Y}=1,031+0,774 \mathrm{X}_{1}+0,769 \mathrm{X}_{2}$. The constant/interception of 1,031 mathematically stated that if the value of the independent variables $X_{1}$ and $X_{2}$ was zero then the value of $Y$ was 1,031. The multiple linear regression equation were explained as followed:

1. The constant number (a) had a positive sign that was equal to 1.031 , meaning that if the variable of the using of the ICT-based media $\left(\mathrm{X}_{1}\right)$, it was considerably constant, and did not question the interest in learning $\left(\mathrm{X}_{2}\right)$, then the learning result $(\mathrm{Y})$ was 1,031.1.031.

2. The coefficient of the using of ICT-based media $\left(b_{1}\right)$ was positive, which was 0.774 . This meant that there was a positive relationship with the students' learning results. If another independent variable had a same value and $\mathrm{X}_{1}$ increased by $1 \%$, so the learning result was increased by 0.774 . Meaning that the higher the use of ICT-based media, the higher the students' learning results in the learning process with the assumption that learning interest variable $\left(\mathrm{X}_{2}\right)$ was considerably constant.

3. The coefficient of the use of ICT-based media $\left(b_{1}\right)$ had a positive sign of 0.774 . This meant that there was a positive relationship with the students' learning results. If other independent variables were not changing and the use of ICT-based media $\left(\mathrm{X}_{1}\right)$ increased by $1 \%$, so the learning result was increased by 0,774 . Meaning that, the higher the use of ICT-based media, the higher the students' learning results in learning with the assumption that the sudents' learning interest variable $\left(\mathrm{X}_{2}\right)$ was considerably constant.

4. The coefficient of the students' learning interest $\left(b_{2}\right)$ had a positive sign that was equal to 0,769 . This meant that there is a positive relationship with the students' learning results. If other independent variables were not changing in the value and the students'learning interest was increases by $1 \%$, so the learning result was increased by 0,769 . Meaning that, the higher the students' learning interest, the higher the students' learning results in learning with the assumption that the variable of the use of ICT-based media $\left(\mathrm{X}_{1}\right)$ was considerably constant.

Based on simultaneous hypothesis testing using the $\mathrm{F}_{\text {test }}$ obtained $\mathrm{F}_{\text {count }}$ of 77,081 , and prob $\mathrm{F}$ of 0.000 . Therefore, $\mathrm{H}_{0}$ was rejected and $\mathrm{H}_{1}$ was accepted, because prob $\mathrm{F}$ was less than the level of significance $(0,000<0,05)$. It was concluded that there was a positive and significant effect on the use of ICT-based media and students ' learning interest to the students learning results. To test the hypotheses partially by using the t test obtained the coefficient 
value of the use of ICT-based learning media $\left(b_{1}\right)$ which was positive, that was equal to 1,045 , $\mathrm{t}$ count was 7,831 , and the $\mathrm{Sig}$ value was 0,000 . Then, $\mathrm{H}_{0}$ was rejected and $\mathrm{H}_{1}$ was accepted because the $\mathrm{p}$-value was less than the significance value ( $\mathrm{Sig} 0,000<0,05)$. It was concluded that there was a positive and significant effect on the use of ICT-based learning media on the students' learning results. Furthermore, the testing of the hypothesis to determine the effect of students $^{6}$ learning interest to the students ${ }^{6}$ learning results obtained the learning interest coefficient value $\left(b_{2}\right)$ positive sign that was equal to $0,945, t_{\text {count }}$ was 9,327 , and the Sig value was 0,000 . Therefore, $\mathrm{H}_{0}$ was rejected and $\mathrm{H}_{1}$ was accepted because the $\mathrm{Sig}$ value was less than the significance value ( $\mathrm{Sig} 0,000<0,05$ ). It was concluded that there was a positive and significant effect on the students' learning interest to the students' learning results.

To know the variable of the use of ICT-based learning media and the students' learning interest which was able to explain the students' learning results, it was necessary to find the determination coefficient $\left(\mathrm{R}^{2}\right)$. The determination coefficient in this research used Adjusted $R$ Square and obtained the output in the model summary as presented in table V below:

TABLE V. MODEL SUMMARY

\begin{tabular}{|c|c|c|c|c|}
\hline Model & $\mathrm{R}$ & R Square & $\begin{array}{c}\text { Adjusted R } \\
\text { Square }\end{array}$ & $\begin{array}{l}\text { Std. Error of the } \\
\text { Estimate }\end{array}$ \\
\hline 1 & $.703^{\mathrm{a}}$ & .494 & .487 & .31374 \\
\hline
\end{tabular}

Table V showed the $\mathrm{R}$ value was 0.703 and the value of Adjusted $R$-Square was 0.487 , if it was seen from the value of R-Square which was 0.494 . It showed that the proportion of the effect of the variable on the use of ICT-based learning media and the students' learning interest variable was $48.7 \%$. Meaning that, the use of ICT-based learning media and the students' learning interest had a proportion of the effect on the students learning result which was $48.7 \%$. While the remaining $51.3 \%$ was influenced by other variables that were not researched or controlled in the study. Besides that, in seeing which variables of the use of ICT-based learning media and the students' learning interest were the most able to provide an explanation of the students' learning result variables, the stepwise method was used. The variable that was first entered was the independent variable with the highest correlation and was significant to the students' learning result.

After being calculated, it was known that the variable that first entered was the variable of the use of ICT-based learning media. So that the variable of the use of ICT-based learning media was the variable that was most able to explain the students' learning result variable. There were no independent variables that were removed from the model because they were all significant. In this case, it was seen also that the change in $\mathrm{R}^{2}$ value when the variable of the use of ICT-based learning media partially entered the model, and obtained the output in the summary model as presented in table VI below:

TABLE VI. MODEL SUMMARY OF THE VARIABLE OF THE UTILIZATION OF THE ICT-BASED MEDIA

\begin{tabular}{|c|c|c|c|c|}
\hline Model & $\mathrm{R}$ & R Square & $\begin{array}{l}\text { Adjusted R } \\
\text { Square }\end{array}$ & $\begin{array}{l}\text { Std. Error of the } \\
\text { Estimate }\end{array}$ \\
\hline 1 & $.528^{\mathrm{a}}$ & .278 & .274 & .37345 \\
\hline
\end{tabular}

Based on Table VI, the partial utilization of ICT-based learning media into the model showed that the $\mathrm{R}$ value was 0.528 and the Adjusted $R$-Square value was 0.274 , if it was seen from the R-Square value which was 0.278 . It showed that the proportion of the effect of the 
use of ICT-based learning media on the students' learning result was $27.4 \%$. Meaning that, the use of ICT-based learning media affected the students' learning result which was $27.4 \%$. Furthermore, the value of $\mathrm{R}^{2}$ when the variable of the interest in learning was entered to the model which obtained the output as shown in table VII below:

TABLE VII. MODEL SUMMARY OF THE VARIABLE OF STUDENTS’ LEARNING INTEREST

\begin{tabular}{ccccc}
\hline Model & R & R Square & $\begin{array}{c}\text { Adjusted R } \\
\text { Square }\end{array}$ & $\begin{array}{c}\text { Std. Error of the } \\
\text { Estimate }\end{array}$ \\
\hline 1 & $.595^{\mathrm{a}}$ & .354 & .350 & .35343 \\
\hline
\end{tabular}

a. Predictors: (Constant), Students' Learning Interst

Table VII shows the interest variable partially entered into the model and obtained an illustration that the $\mathrm{R}$ value was 0.595 and the value of Adjusted R-Square was 0.354 , if it was seen from the value of R-Square which was 0.350. It showed that the proportion of the effect of learning interest variables on the students' learning result was 35\%. Meaning that, the students' learning interest affected the students' learning result which was $35 \%$, and the rest was affected by other independent variables that were not examined or controlled in the research.

Based on the data analysis and the testing hypotheses that had been conducted in this research, the result obtained showed that there was a significant and positive effect on the use of ICT-based learning media and the students' learning interest to the students' learning result in learning. It was in line with the research conducted by Wasa'adah (2015) that examined the use of ICT in the subject of Islamic Education helped students in developing their interest, achievement and changes in students' behavior, if a student wanted to elarn about the Islamic Education, that student was able to quickly learn to understand, remember and practice it [7].

\section{The effect of ICT besed learning media to the students' learning result}

The first objective of this research was to determine the effect of using ICT-based learning media on the students learning result. Based on the data analysis and the testing hypotheses that had been conducted in this study, the result which was obtained showed that there was a significant and positive effect in the use of ICT-based learning media to the students' learning results.

The research finding above proved that the use of ICT-based learning media had a positive and significant effect to the students' learning result in the Islamic education's learning. The information technology included all things related to the process, the use as a tool, manipulation, and management of information. While communication technology was everything related to the use of tools to process and transfer the data from one device to another [8]. Another study that also examined the effect of the using of ICT-based learning media to the students' learning result conducted by Alfany which obtained the results that the use of effective and efficient ICT-based learning media conducted by teachers improved the students' learning results, so that teachers were expected to be able to take the advantages form the implementation of ICT-based learning media in the learning process [9].

By paying attention to the complex and unique learning process, the accuracy of the selection of media and learning methods would greatly affect the students' learning results. Besides that, students' perceptions also greatly affected the learning results. Therefore, in the selection of the media, besides paying attention to the complexity and uniqueness of the learning process, understanding the meaning of perceptions and the factors that affected the 
explanation of the students' perceptions should be conducted optimally so that the learning process was effectively conducted.

\section{The effect of the students' learning interest to the students' learning results}

The second objective in this research was to determine the effect of learning interest to the students' learning results. Based on the data analysis and the testing hypotheses that had been conducted in this study, the results obtained showed that there was a significant and positive effect of the students' learning interest to the students' learning results.

The research finding above proved that learning interest had a positive and significant effect to the students' learning results in the Islamic education learning. This was in line with Sirait who stated that someone who have a high learning interest will be able to follow the learning process well so that it will be able to produce the best performance in learning [5]. Kusnawati stated that there was an effect of the students' learning interest to the students' learning results, so the Islamic education teachers should foster the students' interest in learning for example motivating them to always study hard, displaying various learning methods and media in the learning activities, so it increased students' interest and attention in the islamic education learning in the class [10].

\section{The effect of the using of ICT-based learning media and students' learning interest to the students' learning results}

The third objective in this research was to determine the effect of the use of ICT-based learning media and the students' learning interest to the students' learning results in Islamic education's learning. The findings above, in line with the opinion of Martorell who stated that teachers will provide a new opportunities for interacting students and learn by the tools which were already familiar to them. [11].

The finding of this research proved that the use of ICT-based learning media and the learning interest had a positive and significant effect to the students' learning result in the Islamic education learning. Therefore, it was expected for the teachers, based on the research that had been done by researchers that ICT-based learning media could be practiced in the learning process in the classroom because this media was able to attract the attention of students and improve the students' learning results. Likewise, the students' learning had been proven to have an effect on improving students' learning results positively and significantly. As for schools, because ICT-based learning media used by Islamic education teachers were media that were presented through the use of LCD, it was expected that schools should better support the availability of LCD, books as a means of reading, and also added internet networks (Wifi) so students could access more complete study material. Besides that, through the presentation of the lesson material through the power points by using LCD or the internet, students seriously analyzed the contents of the materials and were directly involved by asking and discussing with their friends about the content of the material displayed by the teacher. Then, the use of ICT-based learning media served to solve the learning problems that were needed in encouraging and motivating students to have the willingness to learn. The essential skills of the 21 st century should include skills for living, the ability to access and analyze information, the ability to utilize the new media and technologies in their learning process, combining technology with pedagogy [3]. Therefore, teachers' skills were needed in mastering technology, knowing when and how to use the current educational technology, as well as choosing skills according to the characteristics of the material to maximize the students' learning results [12]. This ICT-based learning media was used as a support so that students 
were interested in seeing what was explained by the teacher in the classroom and fostered a better spirit of learning[12].

\section{CONCLUSSION}

Based on data analysis and testing hypotheses that had been conducted in this research, the conclusions obtained from these findings were: 1) the use of ICT-based learning media had a positive and significant effect to the students' learning results, 2) the students' learning interest had a positive and significant effect to the students' learning results, 3 ) the use of ICTbased learning media and the students' learning interest in simultaneously had a positive and significant effect to the students' learning results.

Some recommendations as the consideration in improving the Islamic education learning included students being more active in learning and exploring information about everything they wanted to know in order to foster the high interest in learning. Meanwhile, the Islamic education teachers were expected to be able to give direction to students to continue to increase their learning interest in achieving good learning results. The Islamic education teachers were also expected to continue to enrich their knowledge in science and technology, so that they could provide the broad information to students, and were always creative and innovative in conducting the process of teaching and learning activities.

\section{REFERENCES}

[1] S. S. Kaware and S. K. Sain, "ICT Application in Education: An Overview," Int. J. Multidiscip. Approach Stud., vol. 02, no. 1, pp. 26-32, 2015.

[2] M. Lin and H. Chen, "A Study of the Effects of Digital Learning on Learning Motivation and Learning Outcome," EURASIA J. Math. Sci. Technol. Educ., vol. 8223, no. 7, pp. 3553-3564, 2017.

[3] M. I. Supiandi and Y. Lisa, "The utilization of information and communication technology ( ICT ) on learning in the 21st century," Int. J. Acad. Res. Dev. Int., vol. 3, no. 2, pp. 869-875, 2018.

[4] A. D. Pangestu, H. Samparadja, and K. Tiya, "Pengaruh Minat Terhadap Hasil Belajar Matematika Siswa SMA Negeri 1 Uluiwoi Kabupaten Kolaka Timur," J. Penelit. Pendidik. Mat., vol. 3, no. 2, pp. 17-26, 2015.

[5] E. D. Sirait, "Pengaruh Minat Belajar Terhadap Prestasi Belajar Matematika," J. Form., vol. 6, no. 1, pp. 35-43, 2016.

[6] R. Darajaad and D. Fitriyati, "Pengaruh Minat Belajar Dan Jam Belajar Terhadap Prestasi Belajar Siswa Pada Mata Pelajaran Ekonomi Di Siswa Kelas XI IPS 3 SMA Negeri 1 Kesamben Kabupaten Jombang PENGARUH MINAT BELAJAR DAN JAM BELAJAR TERHADAP PRESTASI BELAJAR SISWA Raafiud Darajaad Dhia," J. Pendidik. Ekon., vol. 4, no. 3, pp. 1-6, 2016.

[7] S. Wasa'adah, "Pengaruh intensitas penggunaan media ict dalam pembelajaran pai terhadap motivasi belajar siswa kelas viii smp n 1 banyubiru kab. semarang tahun 2015 skripsi,” Institut Agama Islam Negeri Salatiga, 2015.

[8] S. Pulungan, "Pemanfaatan ICT Dalam Pembelajaran PAI QUERY : Jurnal Sistem Informasi," QUERY J. Sist. Inf., vol. 5341, no. April, pp. 19-24, 2017.

[9] M. M. Alfany, "Pengaruh Pemanfaatan Media Pembelajaran Berbasis ICT Terhadap Hasil Belajar Siswa," Universitas Islam Negeru Maulana Malik Ibrahim Malang, 2016.

[10] E. Kusnawati, "Pengaruh Minat Belajar Terhadap Hasil Belajar Siswa Mata Pelajaran IPS Terpadu Di SMPN 2," Universitas Tanjung Pura Pontianak, 2014. 
[11] M. F. Martorell, "Title: Use of ICT tools in the EFL classroom and their impact on students ' motivation," University De Les Illes Balears, 2017.

[12] S. Subandi, S. Subandi, C. Choirudin, M. Mahmudi, N. Nizaruddin, and H. Hermanita, "Building Interactive Communication with Google Classroom," Int. J. Eng. Technol., vol. 7, no. 2.13, pp. 460-463, Apr. 2018. 